\title{
1982 ANAYASASI'NIN GEÇICI 15. MADDESI ÜZERINE
}

\author{
Prof. Dr. Turgut TAN
}

Rahmetli hocam Prof. Dr. than OZTRAK, 12 Eylül sonrası kurulan huluümetlerde gơrev alan bakanların, çıkar sağlama, görevi kőtüye kullanma gibi eyḷemleri dolayısıyla haklarında soruşturma açıımasına Anayasa'nın geçici 15. maddesinin engel olmadığını açıklayarak (Milliyet Gazetesi, 26 Temmuz 1985) kamuoyundaki duraksamaların giderilmesine katkıda bulunmuştu. Hoca'nın anısına çıkarılan Armağanda bu konuyu biraz daha aynnulı olarak ele almak istedim.

1982 Anayasası'nın Geciçi 15. maddesi Anayasa'nın yürürlüge girmesinden bu yana taruşma konusu yapılan maddelerin başında gelmektedir. Bu madde konusundaki ilk tartışma F-16 uçaklarının seçiminde rüşvet savı ile gündeme gelmişti. ${ }^{1}$ Daha sonra TBMM'nde temsil edilen siyasi partilerin bu maddenin kaldırılması konusuda anlaşuklanına ilişkin haberler basında yer almışsa da somut bir adım aulmamışur. Nihayet 1993 yilına girerken bu kez DYP-SHP Koalisyon Hükümetinin bu maddenin kaldırılması konusunda gerekli girişimde bulunacağı kamuoyuna duyurulmuştu. I. SHPDYP Koalisyonunun sona ermesine karşın bu konuda bir adım aulmamışur.

Anayasa'nın geçici 15. maddesinin kaldırılmasına yőnelik taruşmalarda bir yandan 12 Eylül müdahalesini yapanların. salt bరyle bir müdahaleyi yapmalan nedeniyle yargılanmalan yolunun açılması; ote yandan da, o dőnem yơneticilerinin varsa rüşvet, hırsızlık gibi suçlarının soruşturulmasının ve o donnemin hukuksal tarassuflarının denctlenmesinin istendiłgi gözlenmektedir. Bu bütün bu taruşmalar ozellikle Anayasa'nın geçici 15. maddesinin kapsamanın, yani getirdiği yargı bağışıklığının sınırlarının belirlenmesini zorunlu kılmaktadır. Bu yapılurken geçici 15. madde yanında aynı amaca yönelik bazı yasal düzenlemelerin de ele alınması gerekmektedir. Anayasa Mahkemesi ile Danıştay ve idare mahkemeleri çeşitli kararlarında bu sorunu ele almak olanağı bulmuşlardır. Biz de bu yazı çerçevesinde yargı kararlanndan yararlanarak geçici 15. madde ve dig̣er yasal düzenlemelerle getirilen yargı bağışıklığının anlam ve kapsamını belirlemeye çalışacağız.

\footnotetext{
*H.O. Iktisadi ve Idari Bilimler Fakultìsi Ogretim Oyesi

${ }^{1}$ Bkz. Milliyet Gazetesi, 26.7.1985; Cumhuriyet Gazetesi 19.7.1985; Hurriyet Gazetesi, 1.8.1986.
} 


\section{A. 1982 ANAYASASI'NIN GEÇICI 15. MADDE VE ÖTEKI DÜZENLEMELER \\ A. 1982 Anayasası'nın Geçici 15. Maddesi ve 1961 Anayasası'nın Geçici 4. Maddesi ile Karşılaştırılması}

Anayasanın geçici 15. maddesi, basında, başlangıçıa ileri sürüldügü gibi, 1982 Anayasasina özgü bir düzenleme degildir. Benzer düzenleme 1961 Anayasası'nda (Gecici madde 4) da yer almaktadıs. Dolayısıyla, geçici 15. maddedeki düzenlemeleri, 1961 Anayasasının geçici 4. maddesindeki benzer düzenlemelerle birlikte vermekte yarar gordiuk *

"12 Eylül 1980 tarihinden, ilk genel seçimler sonucu toplanacak. Türkiye Büyük Millet Meclisi'nin Başkanlık Divanı oluşturuluncaya kadar geçecek süre içinde, yasama ve yürütme yetkilerini Türk milleti adına kullanan, 2356 sayılı Kanunla kurulu Milli Güvenlik Konseyi'nin, bu Konseyin yonetimi donneminde kurulmuş hükümetlerin, 2485 sayılı Kurucu Meclis Hakkında Kanunla görev ifa eden Danışma Meclisinin her türlü karar ve tasarruflanndan dolayı haklannda cezai, mali ve hukuki sorumluluk iddiası ileri sürullemez ve bu maksalla herhangi bir yargı merciine başvurulamaz.

"Bu karar ve tasarrufların idarece veya yetkili kılınmı̨ organ, merci ve görevlilerce uygulanmasından dolay, karar alanlar, tasamufta bulunanlar ve uygulayanlar hakkında da yukaridaki fikra hükümleri uygulanır.

(27 Mayıs 1960 tarihinden itibaren Kurucu Meclisin toplandığ 6 Ocak 1961 tarihine kadar yasama yetkisini ve yürütme görevini Türk Milleti adına kullanmış bulunan Milli Birlik Komitesini ve Devrim Hükümetlerinin karar ve tasarruflarnndan ve bunlann, idarece veya yetkili kılınan organ veya mercilerce uygulanmasınŁan dolayı, karar alanlar, tasarrufta bulunanlar ve uygulayanlar hakkında cezai veya mali veya hukuki sorumluluk iddiası ileri sürülemez ve bu maksatla herhangi bir yargı merciine başvurulamaz.) (1961 An. Geçici m. 4/2)

"Bu donem içinde çıkarlan kanunlar, kanun hükmünde kararnameler ile 2324 sayılh Anayasa Düzeni Hakkında Kanun uyannca alınan karar ve tasarruflann Anayasaya aykınlığ iddia edilemez.

(Normal demokratik rejimi bütün teminat ile kurmak amacıyla gerçekleștirilen ve yürütülen 27 Mayıs 1961 Devrimi tarihinden 6 Ocak 1961 tarihine kadar çıkarılan kanunlar, Türkiye Cumhuriyetinin diğer kanunlanının değiştirilmesi ve kaldınlmasında uygulanan kurallara göre deģiştirilebilir veya kaldınlabilir. Ancak, bunlar hakkında Anayasaya aykırılık iddiasiyle, Anayasa Mahkemesinde iptal davası açılamıyacağı gibi, itiraz yoluyla dahi mahkemelerde Anayasaya aykunlık iddiası ileri sürülemez.

27 Mayıs 1960 dan 6 Ocak 1961 tarihine kadar çıkarılan kanunları, yapılmıs tasarrufların ve alınmış kararların deģiştirilmesi veya kaldırılması hallerinde 2 nci fıkra hükmü saklıdır.) (1961 An. Geçici m. 4'3-4)

** Parantez içindeki bölüm geçici 4. madde metnidir. 
Aslında, 1961 Anayasasının geçici 4. maddesi Temsilciler Meclisindeki 1. görüşmede "Kurucu Meclis, Milli Birlik Komitesi ve Temsilciler Meclisinin Hukuki Varlıklarının Sona Ermesi" başlığı alunda birinci fıkradan ibaret bir madde olarak kabul edilmişti. Temsilciler Meclisindeki 2. görüşmede 66 üyenin verdiği onnerge ile maddeye diğer fikralar eklenmiştir. ${ }^{2}$

Otc yandan, oneride maddenin ikinci fikrası "27 Mayıs 1960 devriminin gerçekleş̧irilmesi, yürüttülmesi ve demokratik nizama geçişin sał̧lanması amacıyla, 27 Mayıs 1960 can 6 Ocak 1981 tarihine kadar çukarılan kanunlar hakkında" iken MBK'nda yapılan deģişiklikle 27 Mayıs 1960 ile 6 Ocak 1961 arasında çıkarılmış tüm yasalar hakkıda Anayasa Mahkemesinde iptal davası açılamıyacă̆ı ve itiraz yoluyla dahi mahkemclerde Anayasaya aykırılık savı ileri sürülemiyeceği şeklinde deł̧iştrilmiştir.

Bu deģişiklik Temsilciler Meclisine geldiğinde değişiklił̧in bir karma komisyonda incelenmesi onerilmişse de bu kabul gormemiştir:- Karma komisyonda incelenmesi onerisini destekleyen N. Bilge, bu dónemde çıkarılan yasalar arasında Gümrük Kanunu, Trafik Kanunu, vergi yasaları gibi teknik yasaların bulundušgunu, bunlar hakkında Anayasaya aykınlık iddiasının ileri sürülemeyeceğini, Meclisin kendiliğinden bunlan değiştirmesini beklemenin hükümetlerin harekete geçmemesi nedeniyle gerçekçi olmayacağını belirterck, "200'e yakın teknik kanunlar hakkında Anayasa Mahkemesine müracaat edememck adalet hislerimizi rencide eder" demektedir. ${ }^{3}$

1982 Anayasasının geçici 15. maddesi Danışma Meclisi Anayasa Komisyonu tarafından hazırlanan Tasarının geçici 11. maddesi olarak D.M. Genel Kuruluna sunulmuştur. Madde içerik olarak bugün yürürlükteki geçici 15. maddeden farksızdır. Yalnız, geçici 11. madde iki fıkra halinde düzenlenmiştir. Danışma Meclisinde birinci görüşmeye sunulan geçici 11. madde metsi şठyledir: "12 Eylül 1980 tarihinden, ilk genel seçimler sonucu toplanacak Türkiye Büyük Millet Meclisinin Başkanlık Divanı oluşturuluncaya kadar geçecek süre içinde, yasama ve yürütme yetkilerini Türk milleti adına kullanan, 2356 sayılı Kanunla kurulan Milli Güvenlik Konseyinin, bu Konseyin yőnetim dóneminde kurulmuş hükümeulerin, 2485 sayılı Kurucu Meclis Hakkındaki Karunla gorev ifa eden Danş̧ma Meclisinin her türlü-karar ve tasamuflanndan ve bunlann idarece veya yetkili organ, merci ve görevlilerce uygulanmasından dolayı, karar alanlar, tasarrufta bulunanlar ve uygulayanlar hakkında cezai, mali veya hukuki sorumluluk iddiası ileri sürülemez ve maksalla herhangi bir yargı merciine başvurulamaz.

${ }^{2}$ Onergenin lehinde s $\delta z$ alan H.V. Velidedeo tehlikeye koyan, milletin arzu ve azmini görmüs, dile getirmi̧̧ ve gerçekleştirmiş olan bu subaylarm arsasından (filan tasarruf Anayasaya aykunidır) deyip meseleyi Devlet Surasına veya Anayasa Mahkemesine intikal ettirmek ve bu temiz ihtilali bu sekilde yıpratmak kimsenin hakkı deģildir... Gelecek iktidarlar bu kanunları normal yollarla değiş̧tirecektir. Kanunlar, içtimai bir organizmadır, yıpranır, eskir ve deği̧̧̧irilir. Bunun dışında o halde bu temiz başlamı ve temiz devam etmiş olan ihtilale herhangi bir şekilde gölge konduracak olan hareketlere cevaz ve mesag vermemek lazımdur." demektedir.

Komisyon sőzcüu $M$. Aksoy'da, en az konuşulacak konulardan birinin bu onergeler olduğunu belirtip. önergeye katıldıklarını sőyledikten sonra, önergedeki "cezai ve mali" kelimelerinden sonra "hukuki" kelimesinin de eklenmesini istiyor ve önerge bu şekliyle oylanıp kabul edilmiştir. Bkz. K. Ozturk, Turkiye Cumhuriyeti Anayasası, T. I\$ Bankası yayın, Ankara, 1966, c. 3, s. 3846-3858.

3 ibid; c. 3, s. 3863. 
" Bu dơnem içinde çıkarulan kanunlar, kanun hükmünde karamameler ile 2324 sayıl Anayasa Düzeni Hakkında Kanun uyarınca alınan karar ve tasarrufların Anayasaya aykurılığı iddia edilemez."

Tasanının Danışma Meclisi Genel Kurulundaki birinci gơrüşmesi sırasında bu maddeye ilişkin tek bir deģişiklik onergesi verilmiştir. Bu ơnerge ile maddeye ikinci fikra olarak "Ancak Bakanlar Kurulu üyelerinin görevlerini ihmal ve suistimallerinden dogan mali ve cezai sorumluluklanı bu hükmün dışındadır" hükmünün eklenmesi istenmiştir. ${ }^{4}$ Yaplan oylama sonunda onergenin dikkate alınması kabul edilmemiştir.

Bir üye tarafından 12 Eylül'den sonra kurulan hükümetlerde görev alan bakanlar hakkında Milli Güvenlik Konseyi karan ile yürütülen soruşturmalarun bu madde ile nasıl bağdaşunılacağını sorulması üzerine Anayasa Komisyonu Başkanı verdiği yanıtta, "... bu madde Milli Güvenlik Konseyinin verdiği emirlerin ifası dolayısıyla çıkan sonuçlan ortadan kaldırmaktadır. Yoksa, bakanların kendi şahsi tasarruflannı affetmemektedir, kanun dışı bırakmamaktadır" demektedir. ${ }^{5}$

Geçici 11. madde, Anayasa Tasarısının Danışma Meclisi Genel Kurulundaki ikinci görüş̧mede de taruşmasız kabul edilmiştir.

\section{B. Öteki Yasal Düzenlemeler}

\section{2324 sayılı Anayasa Düzeni Hakkında Kanun}

Anayasanın geçiçi 15. maddesi hükmünù değerlendirebilmek için aynı amaca yơnelik öteki yasal düzenlemeleri de görmekte yarar vardır. 12. Eylül askeri müdahalesini izleyen dơnemde ilk yasal düzenleme 27.10 .1980 tarih ve 2324 sayılı Anayasa Düzeni Hakkında Kanundur. 6

Bu yasa 1 inci maddesinde 1961 Anayasası ve deģişikliklerinin bu konuda belirtilen istisnalar saklı kalmak üzere yeni bir Anayasa kabul edip yürürlüge girinceye yürürlükte oldugu belirtildikten sonra, 2. maddesinde, Anayasa'da Türkiye Büyük Millet Meclisi ve Cumhuriyet Senatosuna ait olduğu belirtilmiş bulunan görev ve yetkileri 12 Eylül 1980 tarihinden itibaren geçici olarak Milli Güvenlik Konseyince, Cumhurbaşkanına ait oldugu belirtilmiş gorev ve yetkilerin de Milli Güvenlik Konseyi Başkanı ve Devlet Başkanınca yerine getirileceği ve kullanılacağı, 3. maddesinde, Milli Güvenlik Konseyince kabul edilerek yayımlanan bildiri ve karar hükümleri ile yayımlanan ve yayımlanacak olan yasaların Anayasa'ya aykınlık iddiasının ileri sürülemiyeceø̆i; 4. maddesinde Milli Güvenlik Konseyinin bildiri ve kararlarında yer alan ve alacak olan hükümlerle 12 Eylül 1980 tarihinden sonra çıkarılan ve çıkarılacak olan Bakanlar Kurulu Karamamelerinin ve üçlü kararnamelerin yürüttülmesinin durdurulması ve iptali isteminin ileri sürülemeyeceği; 6 . maddesinde, Milli Güvenlik Konseyinin bildiri ve kararlarında yer alan ve yer alacak olan hükümler ile Konseyce kabul edilerek yayımlanan ve

\footnotetext{
${ }^{4}$ Imren Aykut ve Kamer Gençi in ortak önergesi için bkz. D.M.T.D. c. 10, s. 512.

$5_{M}$. Z. Bayer'in sorusuna O. Aldıkaçtı'nın yanıtı için bkz. D.M.T.D. c. 10, s. 512.

${ }^{6} \mathrm{RG}$; 28.10.1980, sayı: 17145 .
} 
yayımlanacak olan yasaların 1961 anayasası hükumlerine uymayanların Anayasa deģişiklið̧i, yürürlükteki yasalara uymayanlann da yasa değişikliği olarak yayımladıklan tarihte veya metinlerdeki gősterilen tarihlerde yürürlüge gireceł̧ óngörülmekteydi.

Anayasa Mahkemesi'nin de bir kararında vurguladı̈̆ı gibi, bu yasal düzenlemenin amacı "hiç kuşkusuz, olağanüstü dőnemin olağanüstü koşullannın gerektirdiği işlemlere yasal kolaylık sağlayabilmektir." 7

2324 sayılı Yasa, Anayasa'ya (Geçici m. 3) göre, yapılacak ilk milletvekili genel seçimi sonucunda Türkiye Büyük Millet Meclisi toplanıp. Başkanlık Divanını oluşturdugư tarihte (yani 7.12.1983 tarihinde) yürürlükten kalkmışur. Anayasa'nın geçici 15. maddesi 2324 sayılı Anayasa Düzeni Hakkında Kanun uyannca alınan karar ve tasamufların Anayasa'ya aykırılığının iddia edilemiyeceģi hükmünü getirmiştir.

\section{2968 sayılı Bazı Özlük Işleriyle Ilgili Tasarruflar Hakkında}

Bu Yàsaya (m. 1) göre, "12 Eylül 1980 tarihinden sonra kurulan ve Türkiye Büyülk Millet Meclisi toplanıp yeni Bakanlar Kurulu kuruluncaya kadar geçen süre içinde gorev alan Bakanlar Kurulu, Başbakan ve Bakanların personel atamasına, yer deģioş̧tirmeye, geçici yetki vermeye, görevlendirmeye, görevden uzaklaşurmaya, göreve son vermeye ilişkin işlemleri ile ilgili karar ve tasarruflarından dolayı haklarında cezai; mali veya hukuki sorumluluk iddiası ileri sürülemez ve bu maksatla haklannda herhangi bir yargı merciine başvurulamaz."

12 Eylül 1980 tarihinden geçerli olmak üzere yürürlüğge giren bu yasal düzenleme ile 2324 sayılı Anayasa Düzeni Hakkında Kanun (m. 4 ve 5), anayasanın geçici 15. maddesi hükümleri ve 2577 sayılı ldari Yargılama Usulü Kanununun geçici 1. maddesi dikkate alınarak, " 12 Eylül 1980 tarihinden itibaren 6 Kasım 1983 tarihinde yapılan Milletvekili Genel Seçimi sonucu toplanan Türkiye Büyük Millet Meclisinin gơreve başlamasundan sonra yeni Bakanlar Kurulu kuruluncaya kadar gorrev alan Bakanlar Kurulunun, Başbakanın ve Bakanlann personel atamasına, yer değiştirmeye, geçici yeuki vermeye. görevlendirmeye, görevden uzaklaşurmaya, göreve son vermeye ilişkin işlemleriyle ilgili karar ve tasarruflarından dolayı haklarında cezai, mali veya hukuki sorumluluk ileri sürülemiyeceģi ve Bakanlar Kurulunu oluşturan kişiler hakkında herhangi bir yargı merciine başvurulamayacağı esası" getirilmektedir.

Öe yandan yasa teklifinin gerekçesinde ${ }^{9}$ kişilere yơnelik cezai, mali veya hukuki sorumluluk ileri sürülememesi ve bu amaçla yargı mercilerine başvurulamamasına karşın; Anayasa'daki (m. 129/5) idareye karşı dava açma hakkının da "Anayasa"nın geçici 15. maddesi ve diģer kanunlann buna ilişkin hükümleri gőz onünde bulundurulmak suretiyle ancak" kullanılabilecegi vurgulanmaktadır.

712.9.1991, E. 991/31-K. 991/27, RG; 14.1.1992, say1: 21111, s. 18; 17.3.1992. E. 992/21-K. 992/19, RG: 27.5.1992, say1: 21240, s. 39.

${ }^{8}$ RG; 3.12 .1983 , sayı: 18240 .

${ }^{9}$ MGK uyesi S. Celasuniun Bazı Ozlük işleriyle ilgili Tasarruflar Hakkında Kanun Teklifi ve Milli Güvenlik Konseyi Adalet Komisyonu Raporu. (2/172) Milli Gúvenlik Konseyi S. Sayısi: 743. 


\section{ANAYASANIN GEÇICI 15. MADDESI ILE. GETIRILEN SINIRLAMALAR VE YASAKLAMALARIN KAPSAMI}

Anayasa'nın geçici 15. maddesinin getirdiği sınırlamaların dełgerlendirilmesinden once maddede yer alan düzenlemelerin nitelik ve kapsamları bakımından gruplandırılmasında yarar vardır. Bu açıdan maddede yer alan düzenlemeler ikiye ayrılarak incelenebilir:

* 12.9.1980 ile 7.12.1983 tarihleri arasinda çıarılan yasalarla KHK'lerin ve 2324 sayılı Yasa uyarınca alınan karar ve tasarrufların Anayasa'ya aykırılığının iddia edilememesi.

* 12.9.1980 ile 7.12.1983 tarihleri arasındaki donemde yasama ve yürütme yetkilerini kullanan Milli Güvenlik Konseyinin, MGK yőnetimi doneminde kurulmus hükümetlerin, 2485 sayıl Yasaya göre görev yapan Danışma Meclisinin "her türlü karar ve tasarruflanndan" dolayı haklarında; ayrica, bu karar ve tasarnufların idarece (veya yetkili kulınmış organ, merci ve görevlilence) uygulanmasından dolayı uygulayanlar (karar alanlar ve tasarrufta bulunanlar) hakkında cezai, mali ve hukuki sorumluluk iddiası ile yargı mercilerine başvurulamaması.

\section{A. Yasama işlemleri için Anayasaya Uygunluk Denetimi Yolu Kapatılmıştır.}

12.9.1980-7.12.1983 tarihleri arasındáki dőnemde çeşilli alanlarda 838 yasama işlemi (669 yasa, 90 KHK ile 2324 sayılı Yasa uyarınca çıkarılmıৎ MGK. nin 76 kararı ve 3 bildirisi) yapılmışur. Anayasanın geçici 15. maddesi bu işlemlerin Anayasaya aykırılıgı iddiasında bulunulmasını yasaklamakıadır. Nitekim, Anayasa Mahkemesi de bu işlemlerin Anayasaya aykırı olduklan savı ile yapılan itirazlan geçici 15. madde olanak vermedigi gerekçesiyle, başvuran mahkemenin yetkisizligi nedeniyle reddetmektedir. Yüksek Mahkemeye göre, "Anayasa, geçici 15 maddesi ile bir dơnemin yasal işlemlerinin Anayasa'ya aykırılığ savında bulunulmasını uygun görmemiş, bir anlamda yasaklamıştır. Ancak bunların hukuk devleti ilkesine uygun biçimde yargı denetimine açılması, Anayasa'ya aykırılık savında bulunma ve inceleme yasağının kaldırılmasına bał̆lı olup bu da Anayasa'nın 87. maddesi uyarınca doğrudan yasama organının görev ve yetkisi kapsamına girmektedir." 10

Anayasa Mahkemesine göre "Geçici 15. maddenin de bir Anayasa kuralı olarak, Anayasa'da yer almış bulunan diger kurallarla etki ve değer bakımından eşit olduğunda kuşku yoktur. ${ }^{11}$ Gene Yüksek Mahkemeye gơre, "Yasa kuralının günün sosyal ve ekonomik gerekleriyle çcliştiği sanılsa bile yürürlükte kaldığı sürece uygulanması, hukukun gereğidir... metinlerin anlamlarından başka biçimlerde yorumlanması, metnin bir tür düzeltilmesine kalkışılması, aslında yasada olmayanı yasaya yaklaştırmak ve yorum yoluyla amacını deģiştirmck ya da yasa koyucunun yerini almak olur." 12

\footnotetext{
1012.9.1991, E. $991 / 31 \cdot K .991 / 27$, RG; 14.1.1992, sayı: 21111 , s. 20.

${ }^{11}$ K. 991/27, RG; 14.1.1992, s. 19; ve K. 992/19, RG; 27.5 .1992 , s. 40.

12K. 991/27, RG; 14.1.1992, s. 19; K. 992/19. RG; 27.5.1992, s. 40.
} 
Anayasa Mahkemesi Geçici 15. madenin getiriliş amacını saptarken, "Bu madde kapsamındaki, olaganüstü yönetimin olaģanüstu koşulları alunda çıkanlan yasalarla yasa hükmündeki karamamelerin geçirilen demokratik düzen içinde değiştirilmesine ya da yürürlükten kaldırılmasına değin Anayasa'ya uygunluk denetimi yolu ile belirtilen dønemin taruşma konusu yapılmamasında kamu yararı gorülmüş̧̋̈ir" demektedir. ${ }^{13}$

Yüksek Mahkemenin de isabetle belirtił્̧i gibi, yasa koyucunun, "siyasal ve sosyal gelişmelere ve gereksinmelere göre", bu yasal düzenlemelerden gerekli gördüklerini deģiştirmesine veya kaldırmasına engel bulunmadı̈̆ı gibi, gerekli koşulları yerine getirerek Anayasa'nun geçici maddelerini de kaldırabilir.

Sonuç olarak, 12 Eylül 1980 tarihinden ilk genel seçimler sonucu toplanacak TBMM'nin Başkanlık Divanının oluştuğu 6.12.1983 tarihine kadar geçen dönemde çıkanlan yasalar, KHK'ler ile 2324 sayılı Anayasa Düzeni Hakkında Kanun uyarnnca alınan kararlarla yapılan işlemlerin Anayasa'ya aykın olduğu savında bulunulamaz. Bir başka deyimle, bu dőnemde çıanılan yasalar hakkında Anayasa Mahkemesinde doğrudan iptal davası açılamayacağı gibi, itiraz yoluyla da Anayasa'ya aykurılık savında bulunulamaz. Bunlar hakkında yargı denetiminin açılması Anayasa'ya aykırılık savında bulunma ve inceleme yasağının kaldınlmasına bağlı olup bu da Anayasa'nın 87. maddesi uyannca dogrudan yasama organlarinın görev ve yeukisi kapsamına girmektedir. ${ }^{14}$

Uygulamada bir başka sorun da, belirtilen donnemde çukanldığı için Anayasa'ya uygunluk denetiminden bağışı tutulan yasanın daha sonra deģişiklik geçirmiş hükümlerinin aynı bağışıklıktan yararlanıp yararlanamıyacağı konusunda ortaya çikmaktadır. Anayasa Mahkemesi bu konuda dar bir yorum getirerek, maddenin itiraz

${ }^{13}$ K. 991/27, RG; 14.1.1992, s. 20 ve K. 992/19, RG; 27.5.1992, s. 41.

14 Yuksek Mahkemenin kararına karß̧ı oy yazan bazı uyeler (G. Dinçer) "1961 ve 1982 Anayasalari'nun, bu iki maddesinin mukayesesi, geçici 15. maddenin Anayasa'ya aykunlık iddiasın önlemek için deģil hukuki sorumluluk konusunu çözummemek için konuldư̆ unu" belirterek; "Geçici is inci madde ile ilgili olarak yapılacak engelleyici bir yorum, 1980-, 1983 yıllarında yürürlüge konulan sayıları sekizyuzu bulan güncel bir yasal düzenleme grubunun anayasal denetimini sürekli engelleme demektir. 1961 Anayasasi'nun geçici 4.maddesi ile başlayan ve 1982 Anayasasinın geçici 15. maddesi ile sürdurulen bu durum pek çok konuda. Türkiyejyi anayasası ile deģil anayasanun yasaklayıcı geçici hukumleri ile yönetilen bir ülke olma yúkủ altunda bırakmaktadır." demektedir. (RG; 27.5.1992, s. 43)

Gene Yüksek Mahkeme kararına karşıoy yazan bazı Uyelere (Y. Aliefendioğlu) göre ise, Geçici 15. madde Anayasa'nun 11. ve 148. maddeleri ile çatışmaktadır. "Bu geçici maddenin, sürekli bir kural olarak kabulu durumunda, Anayasanun ongordügu hukuk devleti, Arayasanun ustünlügù ve Anayasal denetimle ilgili temel kurallar, bu dőnemde çıan yasama işlemleri askıya alınmakıadır. Başka bir deyişle, bu dönemde çıkan yasalar ve KHK'ler yơnunden, Anayasa işlerlił̧i kaybetmekte, sơz konusu, yasama işlemleri (hưrriyetçi) demokrasi ve bunun icaplanyla belirlenmiş hukuk düzeninin) dışında kalmaktadır.

"Geçici bir maddenin, Anayasanın temel kurallarını sưresiz işlemez hale getirmesi Anayasal sistemle bağdaşmıacağı gibi, maddenin geçicilik özelliğine de uygun doşmez. Doğaldır ki, geçici maddenin hükmù de geçici olmalıdır." (RG; 14.1.1992, s. 24) Aymı uyeye göre, Anayasanın yürưlüge giri̧̧iyle ilgili 177. maddesi sayılan istisnalar dı̧ında Anayasanın bütünüyle yürürlựe girmesini ongördüzüunden ve geçici 15 . madde bu istisnalar arasında yer almadığından, geçici 15. maddedeki denetim yasağının TBMM .Başkanlık Divaninın oluşturduğu 6.12.1983 dönemiyle sınırlı olması gerekir. (lbid; s. 25). 
konusu bendinde herhangi bir deģişiklik yapılmadığ ve "itiraz konusu kuralın Milli Güvenlik Konseyi'nin yönetimi döneminde çıkarılmış yasa kuralı olma nitelił̧ini yitirmedigi"ni, deģişmeyen bölümün "yürürlüğe girdiği tarihteki yasakoyucunun istencini yansıtuğından onun işlemi niteliği deģişmemiş demektir" diyerek Anayasanın geçici. 15. maddesi karşısında Anayasa'ya aykırılık savının ileri sürülemiyeceğine karar vermektedir. ${ }^{15}$

\section{B. 2324 sayılı Anayasa Düzeni Hakkında Kanun Döneminde} Çıkarılan Bakanlar Kurulu Kararlarına Açılan Iptal Davalari Esastan Incelenebilir:

Danıştay Idari Dava Daireleri Kurulu bazı kararlarında 2324 sayılı Yasa uyannca alınan karar ve tasarruflann en üst norm olan Anayasa'ya aykınlığının iddia edilemiyeceği yolundaki Anayasa hükmü karşısında 2324 sayılı Yasa yürürlükten kalkuktan sonra da yargı denetimine tabi tutulmalarına olanak bulunmadığı gerekçesiyle redderekken; başka bazı kararlarında da, yürürlükten kalkan bir yasanın belli bir maddesinin ileriye yơnelik olarak uygulanabilmesinin bir başka yasanın açık hüküm getirmesi mümkün bulunduğu, Anayasa koyucunun 2324 sayılı Yasa ile getirilen Anayasa'ya aykırılık savına ilişkin yasağı Anayasa'nın geçici 15. maddesi ile sürdürdüğ̈ünü, ancak idari işlemlerin yargısal denetimi konusunda bir yasaklama getirmediğini belinterek davanın esasına girip inceleme yoluna gitmiştir.

Kararlar arasında 2575 sayıh Yasanın 39. maddesinde ungörülen biçimde aykırılık bulundugunu saptayarak içtihatların birleştirilmesi gerektił̆ine karar veren lçthatlan Birleştirme Kuruluna göre, 2324 sayılı Yasanın 2., 3. ve 4. maddeleri "Kanun'un yürürlüge girdigi 28 Ekim 1980 gününden 12 Eylül 1980 tarihine kadar olan geçmis donemi kapsadığı gibi yürürlük tarihinden sonraki dönemi de kapsayacak biçimde düzenlenmiştir. Ancak, bu geleceğe dönüklük geçici olup yeni düzenlemeler yapllncaya kadar sürecek demektir. Bu geçici sürenin sonu da Anayasanın geçici 3. maddesinde belirtilen ve ilk genel seçimler sonucu toplanan Türkiye Büyük Millet Meclisi'nin Başkanlık Divanını oluşturduğu 7/12/1983 tarihidir. Bu hükümlerin uygulanmasının gelecekte sınırsız biçimde süreceği yolunda bir anlayış hukuk mantığı ile bağdaşmaz.

2577 sayılı IYUK'na (m. 7/4) göre ilanı gereken düzenleyici işlemlere karşı uygulamaları üzerine düzenleyici işlem, uygulama işlemi veya her ikisi konu edilerek dava açılabileceğini, dolayisıyle 2324 sayılı Yasanın yürürlükte olduğu dŏnemde çıkarılan karamamelere dayanan uygulama işlemlerine karşı karamameler konu edilerek açılan davaların süreceğini belirten lçtihadı Birleştirme Kuruluna göre Anayasa'nın geçici 15. maddesi Anayasa yargısı yönünden kısıtlamalar getirmiş, "ancak kararname ve işlemlerin idari yargı yerlerince denetimi konusunda hiçbir sınırlama getirilmemiştir."

Anayasa'nın geçici 15. maddesindeki "karar ve tasarruflar" ifadesindeki "tasarruf" deyiminin idari işlemleri de içine alır şekilde yorumlanmasının 2324 sayılı Yasa ile

1512.9.1991, E. 991/31-k. 991/27. RG; 4.1.1992, say1: 21111, s, 17. ren madde "olağan Yasama Organının iradesi doğrultusnda yeni bir anlam ve içcrik kazanmı olmaktave dolayısıyla (deģiştirilmelerine veya yürürlükten kaldırılmalarına değin) Anayasa'ya uygunluk denetimi yoluyla tarışma konusu yapılamıyacă̧ı yasağının dı̨̧ına çıkmı olmaktadır" RG; 14.1.1992, s. 26. 
bağdaşmıyacağı; çünkü idari işlemlerin denetiminin 2324 sayılı Yasanın yürürlükte olduğu dőnemde de serbest olduğunu, yalnız yürütmenin durdurulmasına sınır getirildiğini belirten içtihadı Birleştirme Kuruluna göre, "Anayasa'nın geçici 15 inci maddesinde Anayasa'ya aykırılığının iddia edilemiyecegi belirtilen karar ve tasarrufların yasama tasarrufu niteligindeki karar ve tasurrflar olarak kabulü gerekmektedir.

Sonuç olarak, "7.12.1983 tarihinde yürürlükten kalkan 2324 sayılı Anayasa Düzeni Hakkında Kanun'un 4 üncủ maddesinde yer alan Bakanlar Kurulu kararlan ve üçlü kararnamelerin iptali isteminin ileri sürülemiyeceği yolundaki yasaklamanın halen sürdügüne ilişkin yeni bir kanun hükmü mevcut olmayıp 12.9.1980-7.12.1983 döneminde çıkarılan kararnamelerin 7.12 .1983 tarihinden sonra uygulanan işlemler nedeniyle iptalleri isteğinin idari yargı yerlerinde incelenmesini engelleyen hiç bir Anayasal ve yasal düzenleme bulunmadığından davaların esasına girilerek incelenmesi gerekir. ${ }^{16}$

Bu içtihadı Birleştirme kararından sonra, 2.31982 tarihinde üçlü kararname ile T.C. Ziraat Bankası Genel Müdürlügü müşavirlił̧inden alını Adana Şube Başkontrolörlưgüune kontrolör olarak atanan bir kişinin bu işlemin iptali istemi ile açuğ ${ }_{1}$ dava tizerinde verdiği kararında Danışıay, 12.9.1980 tarihinden sonra çıkanlan Bakanlar Kurulu Karamameleri ve üģlü karamamelerle ilgili olarak 2324 sayılı Yasa ile getirilen yargı denetimi yasağının Anayasa'nın gę̧ici 3. maddesi gereği 17.12.1983 tarihinden sonra kalkuğını, dolayısıyla "bu kararnamelerle yürürlüge konulan düzenleyici tasarruflar hakkında menfaati ihlal edilen ilgililerin 7.12.1983 tarihinden itibaren 60 gün içinde doğrudan doğruya ya da bu tasárruflann uygulanmasıyla ilgili işlemler üzerinde işlemin teblił edildigi tarihten itibaren 60 gün içinde düzenleyici tasarrufun veya düzenleyici tasarrufla birlikte uygulama işleminin iptalini istemesine herhangi bir Anayasal ve yasal engel" bulunmadığını belirtmektedir. ${ }^{17}$

Ancak, dava konusu yapılan 2.3.1982 tarihli üçlü kararname, 2324 sayılı Yasanın 4. maddesi nedeniyle yapıldığ tarihte dava konusu edilememiş, Anayasanın geçici 3. maddesi uyarınca 7.12.1983 tarihinden itibaren 60 gün içinde doğrudan veya 2577 sayıls Yasanın 11. maddesindeki süreç işletilerek dava açılması gerekirken, davanın 15.10.1991 tarihinde açılmış olması nedeniyle süre aşımına uğradığını belirten Danıştaya gơre, davacının kontrolör olarak otanması işlemi, 2324 sayılı Yasa kapsamına girmemesi nedeniyle, tek başına iptal davasına konu yapılabilirse de, davacıyı Genel Müdürlük müşavirliginden alan üçlü kararname ile arasındaki sebep-sonuç ilişkisi gozden uzak tutulmamalidir.

Dolayısıyla, "birinci işlemin iptalinin ikinci işlemi de sebep unsuru yơnünden hukuki dayanaktan yoksun kılacağı; buna karşıllı ikinci işlemin tek başına iptalinin davacıya beklediği yaran sağlayamayacağı açıkur. Iki işlem arasındaki bu yakın hukuki ilişki ve ikinci işlemin birinci işleme hukuksal bağlılığı nedeniyle davacının, 2324 sayılı Yasa kapsamında olmamasına karşın, ikinci işleme karşı birinci işlemle birlikte 7.12.1983 tarihinden itibaren 60 gün içinde aynca dava açılabileceğini de kabul etmek gerekir."

16Danı̧̧tay IBK; 28.2.1991, E. 990/1-K. 991/1, RG; 18.6.1991, sayı: 20905, s. 11 vd.

${ }^{17}$ Danıştay, 5. D; 31.10.1991. E 991/3719-K. 991/2005. DD; sayı: 84-85, 1992, s. 375 vd. 
Ancak, Danıştay, davacının her iki işleme karşı birlikte 15.10.1991 tarihinde açı̆ğ davayı 7.12.1983 tarihinden itibaren 60 günlük süre içinde açılmadığ gerekçesiyle süre aşumı nedeniyle reddetmiştir. ${ }^{18}$

Görüldügü gibi 2324 sayılı Anayasa Düzeni Hakkında Kanunun yürürlükten kalkmasından sonra, 12.9.1980 ile 7.12.1983 tarihleri arasında çıkanılmış olan Bakanlar Kurulu kararlanı ile dił̆er idari işlemlerin idari yargı yerlerince denetlenmesine Anayasa'nın geçici 15. maddesinin engel oluşturmadığı Danıştayın yukanda değindiğimiz kararlan ile açukça kabul edilmektedir.

C. 2968 sayılı Bazı Özlük Işleriyle Ilgili Tasarruflar Hakkında Kanun'un 'Getirdiği Yargı Bağışıklığı: Yasanın getirdiği güvence (kişisel) olup, işlemler güvence kapsamına girmez.

2.12.1983 tarihli ve 2968 sayılls Yasaya (m. 1) göre, "12 Eylül 1980 tarihinden sonra kurulan ve Türkiye Büyük Millet Meclisi toplanıp yeni Bakanlar Kurulu kuruluncaya kadar geçen süre içinde görev alan Bakanlar Kurulu, Başbakan ve Bakanlarnn personel atanmasına, yer deģiştirmeye, geçici yetki vermeye, görevlendirmeye, görevden uzaklaşturmaya, goreve son vermeye ilişkin işlemleri ile ilgili karar ve tasarruflarından dolayı haklarında cezai, mali ve hukuki sorumluluk iddiası ileri sürülemez ve bu maksatla haklarında herhangi bir yargı merciine başvurulamaz."

Danıştay, hakkındaki gơreve son verme işlemi gene Danıştay tarafından iptal edilen ${ }^{19}$ kişinin açıkıa kaldığı süreye ait maddi haklan karşılı ı̆ı maddi tazminat istemi ile ilgili olarak verdiği kararda, 2968 sayılı Yasanın 1. maddesi hükmünü yorumlayarak,

"Madde belirtilen tarihler arasında kurulan Hükümetlerde Başbakan ya da Bakan olarak görev alan üyelerin tek başlarına veya Bakanlar Kurulu olarak yapmıs olduklan idari tasarruflardan dolayı (cezai, mali veya hukuki yönlerden) (şahsen) sorumlu tutulmalarını saģlamak üzere yargı organlanına başvurulamıyacağına işaret etmektedir. Madde, sözü geçen kişilere ongördügü tarihler arasındaki idari tasarruflanndan dolayı (kişisel güvence) getirmekte olup, bu kişilerce tesis edilen idari tasarrufların da bu güvence kapsamına sokulması maddenin sơzüne ve ruhuna aykın düşeceği gibi amacıyla da bağdaşuriamaz.

"Olayda davacı yargı organınca iptal edilmiş gơreve son verme işleminden dolayı uğradığı maddi zararın tazminini, işlemi tesis eden (Bakan)dan değil (bakanlıktan) istediğine göre konunun 2968 sayılı yasanın 1. maddesiyle ilgili bir yönü bulunmamaktadır." denmektedir. ${ }^{20}$

185. D; 31.10.1991, E. 991/37-K. 991/2005, DD; sayı: 84-85, 1992 s. 375 vd.

${ }^{19}$ 5. D; 12.5 .1983 , E $981 / 2013-K .983 / 4048$.

205. D; 10.3 .1988 , E. $986 / 1408-K .988 / 708$, DD; sayı: $72-73$, s. 280 vd. 


\section{12 Eylül Yöneticilerinin Suç Oluşturan Eylemlerini Soruşturmaya Engel Yoktur}

12 Eylül yönetiminin işlemlerinin yargısal denetimi konusundaki sınırlamalann uygulamada yargı organlarınca nasıl anlaşıldığını ve yargı denetiminin işletildiğini gördükten sonra; Geçici 15. madde ile Milli Güvenlik Konseyi üyeleri, o dónemin hükümetlerinde yer alan bakanlann ve Danışma Meclisi tyelerinin, bu organların işlemlerinden dolayı haklarında cezai, mali ve hukuki sorumluluk ileri sürulememesinin ve bu amaçla yargı organlarına başvurulamamasının anlamı üzerinde kısaca durmak gerekir.

Maddenin Danı̧̧ma Meclisi Genel Kurulunda gó́üūsülmesi sırasında Anayasa Komisyonu Başkanının bakanların kişisel tasarruflarını affetmeyece gini açıkça belirttiğine daha ónce değinmiştik. ${ }^{21}$ Bu hükümle getirilen cezai, mali ve hukuki sorumsuzluk, adı geçen organların kurul halinde verdikleri kararlar dolayısıyle sơz konusudur. M. Çemberci'nin beliruiği gibi, "suç niteliģindeki eylem ve davranışlann ise (karar ve tasarruf) kavramlan içerisinde sokulamıyacağı tarışmasızdır. Tersine gơrus eskilerin deyimiyle- (eşyanın tabiatı)na aykın olur idi."22 Aynca, çeşitli bilim adamlan da bu görüş doğrultusunda açıklamalarda bulunmuşlardır. ${ }^{23}$

Bunun böyle anlaşılması gerektiği, Milli Güvenli Konseyi tarafindan oluşturulan hükümetlerde gơrev alan bakanlar hakkında bizzat Konsey tarafından açılan soruşturmalarla da kanılanmaktadır.

\section{A. Meclis Soruşturmaları}

Gcrçekten, 12 Eylül 1980 sonrası Milli Güvenlik Konseyi tarafından kurulan hükümetlerde Maliye Bakanlığı yapmıs olan Kaya Erdem ile Sanayi ve Teknoloji Bakanlığı yapmış olan Şahap Kocatopçu hakkında görevi ihmal ve kotüye kullanma savlanın soruşturmak üzere meclis soruşturması açılmış; yapılan soruşturma sonucunda adı geçen eski bakanlanın Yüce Divan'a sevkedilmelerine gerçek olmadığına "2709 numaralı Türkiye Cumhuriyeti Anayasasmnn 177 nci maddesinin $c$ bendi hükmü delalctiyle 100 üncü maddesi ve Milli Güvenlik Konseyi Yasama Gơrevleri Içtủzügünüun 20 nci maddesi uyarınca, Milli Güvenlik Konseyi'nin 26 Aralık 1982 tarihli 124 uncü Birleşiminde kararlaşurılmışır. ${ }^{24}$

Benzer orneklere genel seçimler yapılıp normal demokratik düzene geçildikten sonra da rastlanilmaktadır. Nitekim, Milli Güvenlik Konseyi tarafindan kurulan hükumetlerde Maliye Bakanlığı yapmış olan Adnan Başer Kafaoğlu hakkında Başak Şirketler Grubundan alacaklı bankaların alacaklarının güvence aluna alınması için emir vererek Anadolu Bankasını ve dolayısıyla Hazineyi zarara ugratmak suretiyle gơrevini kotüye kullandığ ve bu eylemin Türk Ceza Kanununun 240. maddesine uyduğu savı ile Anayasa'nın 100. maddesi uyarınca meclis soruşturması açılması istenmiştir.

${ }^{21}$ Bkz. s. 4, dip not: 5.

${ }^{22}$ M. Çemberci, F-16 Olayı ve Anayasa, Cumhuriyet Gazetesi, 8.8.1985, s. 2.

${ }^{23}$ Prof. S. S. Tekinay ve Prof. E. Teziç"in görưşleri için bkz. Hürriyet Gazetesi, 1.8.1986.

${ }^{24}$ RG; 30.12.1982, sayı: 17914. 
Onerge sahipleri (Kahramanmaraş milletvekili A. Kısakürek ve 51 arkadaşı) Hazineyi zarara sokan operasyonun A.B. Kafaoğu'nun emri ve bilgisi içinde yapıldığın, bu konuda Ekonomik Işler Yüksek Koordinasyon Kurulu veya Bakanlar Kurulu kararı bủunmadığı için Anayasa'nın geçici 15. maddesindeki sorumsuzluk hükmünden yararlanmasının söz konusu olmadığını da vurgulamışlardır. ${ }^{25}$

Ancak, onergenin TBMM'nde görüşülmesine başlandığında usule ilişkin itirazlar olmuş; Anayasa'nın geçici 15. maddesinin onergenin görüşülmesine engel olduğu, madde değiştirilmeden onergenin gorrüşülemiyeceği ve sorunun Anayasa Komisyonunda incelenmesi istenmiştir: ${ }^{26}$ Adalet Bakanı N. Eldem ise yaptığı konuşmada Anayasa'nın geçici 15. maddesinin Bakanlar Kurulu kararlarından söz ettigini belirterek "Hadisemizde Bakanlar Kuruluna yơnelik herhangi bir tasarruf, bir karar mevcut değildir. Bir sabık bakan arkadaşımızın almış olduğu kişisel bir karar vardır. Binanaleyh elma ile armutları toplama kabilinden bir işleme girişmeyelim" demektedir. 27 Sonuçta Anayasa Komisyonuna göndermeye iliş̧in ơnerge reddedildiği gibi, meclis soruşturması açılması da kabul edilmemiştir. 28

\section{B. Meclis Araştırmaṣı}

Bu konudaki ơrnek de Adana milletvekili C. Canver ve 24 arkadaşının hava kuvvetleri eski komutanı emekli org. Tahsin Sahinkaya hakkında Hava Kuvvelleri komutanlığı sırasında kendisine ve ailesine menfaat sağladığı yolundaki iddialan araşırmak amacıyla Anayasa'nın 98. ve içtüzügün 102. ve 103 maddeleri uyarınca meclis araşurması açılması önergesidir. 29

Onergenin TBMM'nde görüşülmesi sırasında ónerge sahipleri adına söz alan C. Canver, "once Anayasa'nın gȩ̣ici 15. maddesi gozetilerck ne yapabileceğimizi, bu şahıslar hakkında soru sorup soramıyacağımızı oğrenmek istedik. Meclis Başkanlık Divanı verdiği yanıtıa (Bu tür iddiaların geçici 15. maddenin kapsamına giremiyeceğini; ancak Başkanlık Divanının Anayasa ile ilgili olarak yorum yapma yetkisinin olmadıgıını, Adnan Başer Kafaoğlu olayında olduğu gibi, bunun ancak Meclis gündemine gelmesi halinde nihai kararın yüce Genel Kurulca verileceğini) belirttiler. Bunun üzerine grubumuz bunu bir meclis araştırması onergesi ile Genel Kurulumuza sunmaya karar verdi" demektedir. ${ }^{30}$ Ancak, onergenin tarışılmasından sonra oylanarak meclis araşurması açılması reddedilmiştir. ${ }^{31}$

${ }^{25}$ T.B.M.M. Tutanak Dergisi, c. 24, s. 415. Bil. 61, 16.2.1986, O: 1.

${ }^{26}$ T.B.M.M. Tutanak Dergisi, c. 24, s. 424. Bil: 61, 16.1.1986, O: 1.

${ }^{27}$ T.B.M.M. Tutanak Dergisi, c. 24 , s. 425 . Bil: $61,16.1 .1986,0: 1$.

${ }^{28}$ T.B.M.M. Tutanak Dergisi, c. 24 , s. 450.

${ }^{29}$ T.B.M.M. Tutanak Dergisi, c. 32 , s. 627 , B: $28,20.11 .1986$, O: 1.

30T.R.M.M. Tutanak Dergisi, c. 32, s. 657 vd.

31T.B.M.M. Tutanak Dergisi, c. 32, s. 671. Bil: 29, 25.11.1986, O: 1. 


\section{- SONUÇ}

Gơrüldügü gibi, 12 Eylül dơnemi işlemleri için getirilen yargı bağışıklığı, bugân yalnızca yaşama işlemleri için Anayasa'ya uygunluk denetimi ile sınurlı olarak sürmektedir. Kaldı ki, bu işlemlerin de yasa koyucu tarafindan herzaman değiş̧irilmesi ve kaldırilması olanağı bulunmaktadır. Buna karşın bu tür yasal düzenlemelere dokunulmayıp 12 Eylül hukukundan yakınmaların sürmesini anlamakta güçlulk çekilmektedir. ${ }^{32}$ Üstelik, kaldurmak veya değiştirmek bir yana bu yasalara dayanılarak işlem yapıldığına da tanık olunmaktadır.

Örneğin, bir üniversite rektőrü, Anayasa'nın (m. 130) "Üniversite yönetim ve denetim organlan ile ơgretim elemanlan, Yükssekơ̆retim Kurulunun veya üniversitelerin yetkili organlarının dışında kalan makamlarca her ne surette olursa olsun görevlerinden uzaklaştınlamazlar" hükmüne karşın, 1982 yılında çıkarılmı̧ 2653 sayılı Yasa ile 2547 sayılı Yasaya eklenen bir hükme dayanılarak Cumhurbaşkanınca görevde uzaklaştırılabilmişdir. ${ }^{33}$

32" Artık insanlarımız, başta TBMM olmak ủzere tüm demokratik kuruluşlardan bir şey bekliyordu: 12 Eylül bitsin.. Bu istem çok doğald, çükủ ozlenen demokrat Turkiye, 12 Eylul'un giydirdił̧i hukưk düzeninin içine sığamazd. Bu olmayacak bir şey de deģildi. Oyle ya, 12 Eylül'ün gadrine uğramı̧ olan tum siỳasi liderler, partileriyle birlikte Meclis'e girmişlerdi ve üstelik hükümet de olmuşlardı." C. Cinmen. Anayasa Mahkemesi Neyi Koruyor? Cumhuriyet Gazetesi, 7.9.1993, s. 2.

${ }^{33}$ Cumhurbaşkanlığının K.S. 93/14 sayılı kararı, RG; 25.6 .1993 sayı: 21618 , s. 2. 